to bile pigment. Earlier workers who attempted to demonstrate the conversion of hæmatin to bile pigment obtained discordant results, but in 1950 London showed by isotope experiments that at least 20 per cent of administered hrmatin is rapidly metabolized to bile pigment. Although the experiments of Grinstein and his colleagues indicate that part of the fæcal protoporphyrin in the dog may be formed from breakdown of hæmoglobin, in man porphyrin excretion can contribute no more than an insignificant amount to the total breakdown products of hæmoglobin. Lemberg has shown that hæmoglobin is oxidized by oxygen in the presence of ascorbic acid to choleglobin, a complex of globin and the iron derivative of a bile pigment. The proportion of the total hæmoglobin broken down by intra-corpuscular degradation of this kind is quite unknown. It seems likely that the dipyrrolic compounds, such as propentdyopents and bilifuscins, are derived from bile pigments subsequent to their excretion by the liver. Isotope experiments have shown that bile pigment can arise not only from cells at the end of a normal life-span, but also by a very rapid mechanism as well as by a slower mechanism not from cells at the end of a normal life-span. In the small intestine, the bilirubin excreted in the bile is reduced to 'fæcal urobilinogen', a mixture of colourless precursors of the pigments stercobilin, urobilin IX $\alpha$ and $d$-urobilin. Baumgartel believes that mesobilirubinogen, the precursor of the optically inactive urobilin $I X \alpha$, is formed only in the liver, but Watson has contested this view. The determination of frcal urobilinogen has been much used as a rough measure of hæmoglobin breakdown. Interpretation of the results obtained must, however, always take into account certain limitations: urobilin and urobilinogen are converted into other substances not estimated by the Ehrlich reaction; and hæmoglobin may break down directly into dipyrrolic compounds, or other unknown substances. The very high proportion of bile pigment not formed from old red cells may occur in other diseases as well as in pernicious anæmia and congenital porphyria.

Dr. J. C. Houston outlined the view that the body is unable to excrete iron, and that the amount of this element within the body is normally regulated by its absorption, which is strictly limited, according to the needs of the tissues. Apoferritin of the duodenal and intestinal mucosa appears to act as an acceptor. When all the apoferritin has combined with iron to give ferritin, no more iron can be absorbed until some has been given up to the plasma. The factors controlling the rate of release of iron from the mucosal ferritin into the plasma are obscure. The total jron-binding capacity of plasma is normally only about one-third saturated. In hæmochromatosis, serum iron is always above normal, and there is complete or almost complete saturation. The serum iron of hæmochromatosis patients does not increase after oral ferrous sulphate as does that of a normal person. Attempts using radioactive iron to determine the absorption of iron and the amount laid down in the tissue stores have given discordant results, either because of technical difficulties in measuring fæcal radioactivity or because patients have been investigated at different stages of the disease. Very little isotope passed into the blood, presumably because of dilution by a pool of physiologically available iron that is larger than normal. That some of these enormous deposits of iron in hæmochromatosis are available for regeneration of hæmo- globin has been shown by the failure of these patients to become anæmic even after repeated large bleedings. Patients with hæmochromatosis can thus regenerate hæmoglobin at a great rate, and it seems likely that it is the small reserve of available iron which limits the rate of hæmoglobin regeneration after hæmorrhage.

In the subsequent discussion, Dr. W. W. Payne emphasized the importance of the mucosal block in the absorption of iron by reporting a case of fersolate poisoning in which the serum iron concentration reached $20 \mathrm{mgm} . / 100 \mathrm{ml}$, consequent to the destruction of the intestinal mucosa. In reply to a question from Prof. N. F. Maclagan, Prof. Gray observed that 'fæcal urobilinogen' determinations are of some value in the diagnosis of hæmolytic disease. Prof. H. Munro Fox described how hæmoglobin synthesis in the crustacean Daphnia is greatly stimulated by oxygen lack and how, on re-oxygenation, the extra hæmoglobin rapidly disappears, apparently without bile pigment formation. Dr. J. C. White referred to the observation of Haurowitz, that the oxidation of fatty acids is coupled with the breakdown of hæmoglobin to colourless products. Dr. T. With remarked that in the horse the serum bilirubin is much greater than in man, yet in the horse the bile contains very little bilirubin. Dr. M. G. Cood was of the opinion that the thyroid influences hæmopoiesis.

\section{EDUCATION IN CHEMISTRY}

A

DISCUSSION on education in chemistry was held on February 18, under the joint auspices of the London Sections of the British Association of Chemists and the Royal Institute of Chemistry. This attracted an audience of about two hundred people, not only from the London area, but also from various other parts of Britain. Introductory talks were followed by an animated discussion, and altogether twenty-one people spoke in the course of just under three hours. They were representative of the University of London, the Royal Institute of Chemistry, technical colleges, technical schools, the Ministry of Education and industry.

The five introductory speakers dealt with distinct facets of the subject. Prof. C. K. Ingold (University College, London) spoke about the aim of the revised regulations for the Special degree in chemistry of the University of London. A specialist in chemistry, he said, should reach a standard at which he has studied some aspects in sufficient detail, in order to have the right to form an independent judgment. At the same time, the conventional barriers between chemistry and other sciences are breaking down, and it is necessary for chemistry specialists to have a broad background in other sciences. Prof. Ingold thought that sufficient experience has been gained with the Internal degree of the University to be sure that the students trained under the revised regulations are better developed than those trained under the old regulations.

Dr. J. H. Skellon (Acton Technical College) spoke about External degrees in chemistry of the University of London, mainly from the. point of view of the technical colleges. $\mathrm{He}$ described ways in which these colleges are adjusting their arrangements to fulfil the additional requirements of the new regulations, and thought that there is a danger of the main 
subject being neglected in the first years of the course. He felt that the new regulations for the External degree should be reconsidered at the end of an experimental period of, say, five years. A point of serious concern is that a student has to decide at the Intermediate science stage whether he will work for the General degree or for a Special degree, and he felt that this is too early a stage for a specialist to be selected. The old arrangement, whereby a man could take the General degree and, one year later, a Special degree, had a distinct advantage.

Prof. Harold Burton (Queen Elizabeth College, London) said that the only professional qualification in chemistry, apart from the Special B.Sc. degree and the associateship of certain technical colleges, is the associateship of the Royal Institute of Chemistry. The Institute had 3,174 registered students at the end of 1952. Approximately three hundred have entered for the examinations in April, and the normal percentages of passes is of the order of 25 per cent. This qualification places more emphasis on practical work than the University of London degree. $\mathrm{H}_{\Theta}$ pointed out that many candidates are found to be weak in physical chemistry.

Mr. R. W. Blount (Ministry of Education) discussed National Certificates in chemistry, which are qualifications below the professional level. This scheme has been in operation since 1921, and he felt that, apart from providing an indication of the level of training of chemical assistants, it has a distinct value in encouraging organized part-time courses, in raising the standard of accommodation and equipment at many technical colleges, and in bringing students into early contact with their professional institution. $\mathrm{He}$ said that the numbers of candidates for the Ordinary National Certificate in chemistry has risen from 358, with 245 passes, in 1946 to 1,285 , with 729 passes, in 1952. For Higher National Certificate the increase has been from 112, with 83 passes, to 593 with 364 passes. Further increase is probable, particularly as opportunities for part-time day-study increase.

Dr. Norman Booth (British Oxygen Co., Itd.) talked about the requirements of industry, in which two out of every three qualified chemists are employed. He stressed that only about one-third of the qualified chemists in industry are engaged on research work, and that more than 8 per cent are engaged on administrative work of various types, including departmental management and membership of boards of companies. This is a growing tendency which should be taken into account when considering the education of chemists. A man with only scientific and technical knowledge will have a limited scope in industry, and the universities should foster other qualities essential both for senior technical and for administrative posts. Dr. Booth also referred to the value to industry of integration of the respective courses for the National Certificate and for the associateship of the Royal Institute of Chemistry.

The discussion which followed covered a wide range of subjects and is not easily summarized. Some purely factual matters raised were answered by the opening speakers. A number of contributors considered that the Special degree in chemistry, although perhaps suitable for those who will become outstanding academic workers, covers too much detail for most chemists' needs. It was believed that a course which pays particular attention to the principles of chemistry and puts more emphasis on practical training would be more valuable generally. Some desirable features are difficult to achieve; for example, a practical examination in physical chemistry cannot be adopted because of lack of examination facilities.

Many speakers referred to the question of flexibility and integration of courses, the object being to enable a person to change from one type of course to another without necessarily having to start at the bottom of the new course. It was generally felt that there could be improvements in the present system. It was suggested that bursaries should be made available to enable promising persons with Higher National Certificate in chemistry to study as full-time students for a degree, either in pure science or a technology.

It was pointed out that the University of London has taken distinct steps to ease the way for admission of students from technical secondary schools, which for some young people might provide the best approach to the chemical profession. Thus, for example, people of mature years are no longer required to have passed a preliminary examination in a foreign language. The ordinary National Certificate in chemistry is regarded as part-fulfilment of the entrance qualification. Further, in the General Certificate of Education, it is not necessary to take all the subjects at once, as was the case with the old matriculation examination.

Mr. L. E. Ball said that the University of London is revising many of the degree courses; but it has not been possible to bring them all into operation at once. He referred particularly to revised General degree regulations which will require the student to take three subjects in his first post-intermediate year and two subjects for a further two years.

Dr. H. B. Nisbet thought it might be possible to arrange a system so that at about General degree standard a person could decide to proceed either to take a technological course or, if he intended to go into research, to take the Special chemistry course. In this way industry would be able to recruit men with training more appropriate to the type of work they are going to do than is the case at present.

It was noted that there is a class of worker in industry, namely, the process worker or plant operator, who would benefit from instruction in the chemical principles underlying the processes he is operating. Although some industrial concerns themselves provide this training, co-operation with the local technical colleges might well be extended.

Other points which arose in the discussion were the continued shortage of teachers of chemistry in schools and its future effect on higher education in chemistry; the necessity for teaching students to express themselves in simple and unambiguous language; the desirability of industry revising its recruiting standards, for example, by taking more people with a General degree and placing less emphasis on a degree with honours in Special chemistry ; and how far attempts should be made to educate chemistry students in the humanities.

It is probable that no single point raised during the discussion would have met with unqualified agreement. It was clear, however, that there is no smug satisfaction with the present system of education, and that there are many constructive ideas for improvement. The education of chemists is evidently receiving serious attention by all sections of the chemical community, and perhaps the one 
thing on which all would agree is that methods of teaching, the content of courses and the regulations must all be adjusted at suitable intervals of time in the light of new knowledge and new demands.

NORMAN BOOTH

\section{ROYAL COMMISSION ON AWARDS TO INVENTORS}

$\mathrm{T}$

HE Royal Commission on Awards to Inventors, under the chairmanship of Lord Cohen, which was appointed in 1946, has now submitted a third report containing a general survey of the principles which have guided its decisions and some particulars of the more important claims dealt with up to November 8, 1952.

Since hearings started in February 1947, the Commission has sat in public on 278 days and disposed of 325 cases. Many of the claims have presented features of great complexity and have involved hearings extending over several days. About 255 cases were withdrawn after being referred to the Commission. This large number of withdrawals indicates that the procedure adopted by the Commission for enabling the claimant and the government department concerned to set out their case in writing in the first instance has been useful in clarifying and leading to the settlement of many difficult cases without recourse to a hearing.

The Commission, under its terms of reference, can only deal with those cases referred to it by the Treasury or the government department concerned. To assist the department in determining which cases should be referred, the chairman, at the request of the Treasury, set up an Investigating Committee consisting of two or three members of the Commission who carefully examine all claims submitted to it. This Committee has dealt with about 280 claims. Many of the claims comprised several inventions which had to be considered separately.

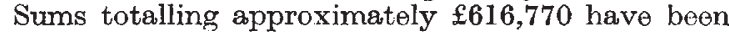
awarded since the Commission began its work. By far the largest number of claims has been on an ex gratia basis-that is, where the claimant has no legal right to payment but relies upon the bounty of the Crown. Under this heading, for example, the Commission has awarded a total of $£ 94,600$ to the inventors of radar installations, including $£ 50,000$ to Sir Robert Watson-Watt. A further series of claims for which a total of $£ 23,300$ was recommended concerned the inventions (generally known as 'degaussing') used on ships to counteract the German magnetic mine. Other claims concerned the 'Fido' project for dispersing fog from airfields, the 'Leigh' light for aircraft used in anti-submarine warfare and the 'Morrison' table shelter for air-raid protection.

The Commission has also dealt with several legal claims based on the use of patents, in these cases acting in lieu of the High Court. One of these inventions concerned stabilizing gear for reducing the rolling of ships, and the Commission awarded the claimants $£ 27,500$.

The Commission has continued the shortened procedure for dealing with claims, for this procedure provides a claimant with a more expeditious and less expensive means of bringing his claim to a hearing.

Although there is still a considerable number of claims outstanding, which the Commission will deal with as and when it is ready for hearing, it can now be claimed that the major part of the task allotted to the Commission has been accomplished.

\section{COMMONWEALTH FUND}

\author{
ANNUAL REPORT FOR 1951-52
}

$\mathrm{T}$ HE thirty-fourth annual report of the Commonwealth Fund*, founded on October 17, 1918, by Mr. Stephen V. Harkness (whose residence, Harkness House, New York, was bequeathed to the Fund and is occupied as its headquarters), covers the year ended June 30,1952 . Of the $2 \cdot 7$ million dollars appropriated during the year, 39 per cent was for medical education, 16 per cent for experimental health services, 15 per cent for medical research and 8 per cent for fellowships, including advanced fellowships in medicino and allied fields, particularly for work involving the crossing and re-crossing of interdisciplinary frontiers, and thirty-one British fellowships and nine Salzburg fellowships. The report lists the thirty research projects currently aided by the Fund; and, of the nine which were new or renewed during the year, six relate to integrative processes in man or to crucial factors in the adjustment of man to this environment.

The major interest of the report, however, lies in its account of the experimental work in medical education and in health services supported by the Fund and of the ideas which are guiding these experiments. In medical education, the experiments turn on the assumption, still to be verified, that medical teaching organized around the student's need to learn and the patient's need for care, will prepare students to meet the responsibilities of medicine as a social institution more effectively than medical teaching organized around the preoccupation of teachers with what they as specialists think they ought to teach. To the five-year grant made in 1950 for the reorganization of the curriculum at the Western Reserve School of Medicine, a further grant of 276,428 dollars has been added. This will facilitate a reorganization in which the initial two phases will occupy about two and a half years ; first, the student is oriented to medicine and to the patient, presenting the fundamental principles of man's structure, function, growth, behaviour, and relation to his environment; and then, during the second phase, dealing with disease (by general principles and afterwards by organ and site), the teaching will be done by interdepartmental teams on which each man will teach what he is best fitted for ; the third and final phase of the reorganization will take a further eighteen months and will deal with the care of sick people.

The second group of experiments embraces grants to the University of Colorado School of Medicine and to the Cornell University Medical College for studies relating to teaching and learning by contact with patients in the clinical years of the medical course, conducted in a new kind of elinic which will put a premium on continuity and comprehensiveness in medical care. If the experiments succeed, they should assist in providing answers to some of the outstanding questions regarding the relation of generalized to specialized medicine, the responsibility for insight into the patient's total problem and the like. The Fund has also made a new grant for the support of the "family general practice" clinic begun at the University of Tennessee College of Medicine in the autumn of $195 \mathrm{l}$, and one of 200,000 dollars for the expenses of a working-party for three years to devise

* Commonwealth Fund. Thirty-fourth Annual Report for the Year ending June 30,1952 . Pp. xiif +42 . (New York: Commonwealth Fund, 1952.) 